\title{
ANALISIS HUKUM ISLAM TERHADAP SANKSI PEMBATALAN KHITHBAH NIKAH
}

\author{
Sudirman \\ IAIN Metro Lampung \\ sudirmanhk1@gmail.com
}

\begin{abstract}
Khithbah is an important process in marriage because it becomes the gateway. In order to maintain the continuity of the process towards the marriage level and keep the parties from the losses due to the unilateral cancellation of khithbah that is rampant, the leaders of Gaya Baru 3 and Gaya Baru 5 make a khitbah agreement with certain sanctions. This paper examines how the covenants of khitbah, peningset, and other material fines and their implications for the maqashid of sharia. The finding is that the practice of the khitbah covenant can be justified in the spirit of the Compilation of Islamic Law and the opinion of the madhhab scholars. It's just that the nominal fines are too large to make the parties objected so do legal hillah that actually hit the maqashid sharia of marriage.
\end{abstract}

Keywords: khithbah, peningset, sanctions of the khitbah covenant

\begin{abstract}
Abstrak
Khithbah adalah proses yang penting dalam pernikahan karena menjadi pintu gerbang. Demi menjaga keberlangsungan proses menuju jenjang pernikahan dan menjaga para pihak dari kerugian akibat pembatalan khithbah secara sepihak yang marak terjadi, tetua kampung Gaya Baru 3 dan Gaya Baru 5 membuat perjanjian khitbah
\end{abstract}


134| Sudirman

dengan sanksi tertentu. Tulisan ini mengkaji bagaimana perjanjian khitbah, hadiah khithbah atau peningset, denda materi lain dan implikasinya terhadap maqashid syariah. Temuannya adalah bahwa praktik perjanjian khitbah bisa dibenarkan dalam spirit Kompilasi Hukum Islam dan pendapat ulama madzhab. Hanya saja, nominal denda yang terlampau besar membuat para pihak keberatan sehingga melakukan hillah hukum yang justru menabrak maqashid syariah dari pernikahan.

Kata Kunci: khithbah, peningset, sanksi pembatalan khithbah

\section{Pendahuluan}

Pernikahan dalam hukum Islam menepati posisi yang sangat penting. Ia adalah tulang punggung terbentuknya keluarga baru yang diakui oleh agama dan masyarakat. Ia menjadi soko guru bagi terbentuknya tatanan masyarakat yang teratur dan tertib. Sebab itulah, Islam menyebut ikatan pernikahan sebagai mitsaqan ghalidzan atau ikatan yang sangat kokoh. Ada banyak maqashid syariah dharuriyah yang bisa dicapai dengan pernikahan ini, mulai dari menjaga agama (hifz din), menjaga nyawa (hifz nafs), hingga menjaga keturunan (hifz nasl).

Mengingat penting dan krusialnya pernikahan dalam Islam, juga karena ia melibatkan dua pihak dengan dua keluarga besar, maka jalan menuju jenjang pernikahan melewati banyak prosesi. Salah satu prosesi awal (muqoddimatuz-zawaj) menuju pernikahan adalah meminang, lamaran atau khithbah. Ini adalah penjajagan bagi keluarga satu dan keluarga dua untuk saling mengenal dan mengkomunikasikan hasrat untuk menjodohkan putra/putri mereka. Di titik inilah komitmen awal dua keluarga diikrarkan dan diteguhkan.

Akan tetapi, dalam kenyataannya tidak semua apa yang diikrarkan bisa terus berjalan dengan baik sesuai rencana. Ada kalanya pihak tertentu menciderai janji karena satu dan lain persoalan. Hal ini bisa saja terjadi di berbagai wilayah. Masyarakat kemudian berupaya membuat pranata untuk menjaga janji tersebut. Masyarakat Kampung Gaya Baru 3 dan Gaya Baru 5 
di Kecamatan Seputih Surabaya dan Bandar Surabaya memiliki pranata sosial untuk menghadapi hal ini, yakni dengan membuat perjanjian khithbah dengan sanksi yang cukup besar bagi yang melanggarnya.

Mempertimbangkan besarnya sanksi yang diancamkan, banyak pihak berupaya menghindarinya, bahkan dengan menyelenggarakan pernikahan secara formalitas belaka. Seusairesepsi perkawinan, masing-masing mempelai kembali ke keluarga masing-masing. Artikel ini berupaya mendeskripsikan lebih detil bagaimana proses perjanjian tersebut berjalan dan bagaimana hukum Islam memandang akad tersebut.

\section{Munculnya Perjanjian Khithbahdi Bandar Surabaya dan Seputih Surabaya}

Bandar Surabaya dan Seputih Surabaya mulanya adalah satu kecamatan, yakni kecamatan Seputih Surabaya.Karena adanya program pemekaran,terbentuklahkecamatan baru yakni Kecamatan Bandar Surabaya. Di sisi yang berbatasan pada dua kecamatan tersebut terdapat kampung Gaya Baru 3 (Seputih Surabaya) dan Gaya Baru 5 (Bandar Surabaya). Mayoritas penduduk dua kampung tersebut merupakan transmigran dari Wonosari, Yogyakarta, sehingga di kampung Gaya Baru 3 tersebut terdapat dusun Jogja 18 dan di Gaya Baru 5 terdapat dusun Jogja 5. Mereka menempati dua dusun tersebut pada 1996 setelah dua tahun transit di Kecamatan Rumbia.

Warga di dusun Jogja 5 dan Jogja 18 ini melaksanakan praktik khithbah atau pertunangan dengan perjanjian khusus. Perjanjian khithbahini bermula ketika seorang laki-laki meminang perempuan kemudian membatalkan khithbahtersebut. Seorang sesepuh kampung, Kasmo menuturkan bahwa pada 1982,ia pernah dimintai bantuan keluarga Surono bin Donorejo untuk melamarPainah binti Mangun.Beberapa waktu kemudian, pihak calon mempelai perempuan membatalkan khithbah. Pada era tersebut, terdapat beberapa kasus pembatalan khithbah. ${ }^{1}$

2016.

${ }^{1}$ Kasmo, Sesepuh Bandar Surabaya dan Seputih Surabaya, 13 Februari 
Para tokoh masyarakat ataupun tua-tua kampung kemudian menggelar rapat. Pada 1992 dicapailan suatu keputusan perjajian khithbah. Barang siapa yang membatalkan khithbah atau pertunangan maka dikenakan sanksi atau denda sebesar Rp.1.500,- (Seribu lima ratus rupiah).Pada tahun tersebut, tidak ada perjanjian tertulis tetapi aturan tersebut berlaku. Semenjak 1998, perjanjian tersebut terus berlaku dan nominal denda terus meningkat dari waktu ke waktu.Pada tahun 2015-2016, nominal dendanya mencapai angka Rp 20.000.000,- (Dua puluh juta rupiah) atau terkadang lebih besar, sesuai kesepakatan dua belah pihak.

\section{Prosesi Khithbah di Kecamataan Seputih Surabaya dan Bandar Surabaya}

Prosesi pra-khithbahbiasanya diawali dengan takon(Jw) atau nakokne(Jw), yang dalam bahasa Indonesia bermakna "menanyakan". Dalam prosesi ini,pihaklaki-lakimelalui perantara atau secara pribadi bertanya kepada pihak perempuan apakah si gadis sudah ada ikatan atau belum. Jika pihak perempuan memberikan jawaban belum ada ikatan (legan), apakah ia setuju jika hendak dipinang? Jika setuju, baik wali/orang tua maupun si gadis, langkah selanjutnya adalah khithbah atau pertunangan.

Bagi warga Dusun Jogja 5 (Gaya Baru 5) dan Jogja 18 (Gaya Baru 3),nakoknesudah menjadi hal yang lumrah. Pernikahan yang tidak diawali dengan nakokne akan menjadi sesuatu yang ganjil, menimbulkan fitnah dalam masyarakat.Dalam tahap nakokneini, tidak ada peraturan yang mengikat (dapat pula disebut dengan pra-khithbah atau pra-tunangan).

Tahap kedua adalah khithbah atau pertunangan yang pada umumya dihadiri serta disaksikan oleh tokoh masyarakat, tokoh pemuda, dan perwakilan tetangga. Khithbah atau pertunangan disertai dengan cinderamata (peningset atau singsetan) yang dapat berupa gelang, kalung, ataupun cincin emas sebagaitanda jadi untuk melangsungkan perkawinan. Pertunangan (khithbah) yang disertai denganperundingan pertunangan, yakni adanya kesepakatan kedua belah pihak untuk menuju pernikahan. 
Jika dalam pertunangan tidak terjadi kesepakatan,maka pertunangan bisa menjadi batal.Akan tetapi, bila terjadi kesepakatandi antara kedua belah pihak, maka pertunangan dilanjutkan. Biasanya, dalam prosesi inilah terjadi perjanjian pembatalan khithbah dengan sanksi yang disepakati bersama. Kesepakatan ini disaksikan oleh para saksi dan para tokoh masyarakat.Apabila ke depan terjadi pembatalan khithbah dari salah satu pihak, maka konsekuensinya adalah siap menanggung sanksi atau denda yang telah disepakati.

Pada saat seperti inilah pihak peminang atau yang dipinang harus berhati-hati dalam menjaga diriuntuk dapatlanjut pada jenjang pernikahan.Pertunangan atau khithbah di Dusun Jogja 18 dan Jogja 5 tidak seluruhnya menggunakan perjanjian hal tersebut, karena hal ini menyangkut kesepakatan kedua belah pihak.Jika keduanya sepakat menggunakan perjanjian pembatalan khithbah, kedua pihak baru membicarakan nominal sanksi. Perjanjian ini kemudian dicatat dan ditandatangani dengan mengisi formulir yang disediakan oleh tetua kampung.

\section{Sanksi atas Pembatalan Khithbah di Kecamatan Seputih Surabaya dan Bandar Surabaya}

Pembatalan khithbah diatur sesuai kesepakatan bersama, demikian juga dengan denda atau sanksinya.Namun demikian, di kalangan tetua masyarakat, aparat kampung, Bayan atau Kadus, tokoh pemuda, dan pamong kampung telah memiliki kesepakatan bersama agar diterapkan perjanjian pembatalan khithbah. Hal ini merespons banyaknya pembatalan khithbah tanpa adanya alasan yang jelas.

Pada tahun 1999, nominal denda yang harus dibayarkan oleh pihak yang membatalkan khithbah adalah sebesar Rp 2.500.000 (Dua juta lima ratus ribu rupiah). Nominal denda ini kemudian pada 2008 naik menjadi Rp 5.000.000 (Lima juta rupiah). Pada 2010, nominal ini naik menjadi Rp 10.000.000 (Sepuluh juta rupiah). Pada tahun 2013 sampai 2017, denda yang diterapkan adalah 20.000.000 (Dua puluh juta rupiah). ${ }^{2}$ Nominal

${ }^{2}$ Mino, Kadus Jogja 5, Kampung Gaya Baru 5, Bandar Surabaya, 21 Januari 2016. 
ini berlaku umum di Jogja 5 dan Jogja 18. Adapun sanksi khusus yang diterapkan di Jogja 18 adalah banjar pekarangan, atau rumah beserta isi dan pekarangan. ${ }^{3}$

Secara geografis, Gaya Baru III berdampingan dengan Gaya Baru V, sehingga mekanismeperaturan yang diterapkan tidak jauh berbeda.Letak perbedaan hanya pada nominal dendayang diterapkan. Pada akhirnya, perjanjian khithbah yang telah disepakati bersamamenjadiperaturan yang mengikat di wilayah tersebut.Apabila pihaklaki-laki membatalkan khithbah, maka dikenakan sanksi sesuai nominal yang telah disepakati ditambah dengan singsetan tidak dikembalikan (termasuk barang bawaan dan perhiasan).

Jika pihak perempuan membatalkan khithbah, maka ia dikenakan sanksi sesuai nominal yang disepakati ditambah dengan mengembalikan singsetan (gelang, kalung, cincin yang pernah diberikan pihak lelaki). Pengembalian denda tersebut dibagi menjadi dua bagian: untuk pihak yang digagalkan dan untuk kas aparatur kampung Gaya Baru V.Jika nominal sanksi sebesar Rp. 10.000.000,00 maka Rp. 9.000.000,00 untuk pihak yang digagalkan dan Rp.1.000.000,00 untuk kas kampung. ${ }^{4}$

Tabel 1. Daftar nama-nama yang melakukan perjanjian khithbah periode2013-2015.

\begin{tabular}{llll}
\hline \multicolumn{1}{c}{ Laki-Laki } & \multicolumn{1}{c}{ Perempuan } & $\begin{array}{c}\text { Nominal } \\
\text { Denda }\end{array}$ & \multicolumn{1}{c}{ Singsetan } \\
\hline $\begin{array}{l}\text { Dedik Irawan } \\
\text { bin Riyadi. }\end{array}$ & Sari Widiawati & Rp.10.000.000,- & $\begin{array}{l}\text { Cincin 5gram } \\
\text { Kalung 6 gram } \\
\text { ditambah } \\
\text { seperangkat } \\
\text { pakaian }\end{array}$ \\
\hline $\begin{array}{l}\text { Frandika Bin } \\
\text { Samino }\end{array}$ & Santi Binti & Rp.10.000.000,- & $\begin{array}{l}\text { Seperangkat } \\
\text { pakaian }\end{array}$ \\
\hline
\end{tabular}

${ }^{3}$ Banjar pekaranganadalah sebutan bagi satu unit rumah beserta isi dan pekarangannya.

4 "Arsip Surat Perjanjian Khithbah di Gaya Baru 5, Bandar Surabaya," n.d. 
Analisis Hukum Islam terhadap Sanksi Pembatalan Khitbah Nikah |139

\begin{tabular}{|c|c|c|c|}
\hline Laki-Laki & Perempuan & $\begin{array}{c}\text { Nominal } \\
\text { Denda }\end{array}$ & Singsetan \\
\hline $\begin{array}{l}\text { Surahman Bin } \\
\text { Sudaryanto }\end{array}$ & $\begin{array}{l}\text { Partiyem binti } \\
\text { Sumono }\end{array}$ & Rp.10.000.000,- & $\begin{array}{l}\text { Kalung emas } \\
5 \text { gram }+1 / 2 \\
\text { gram (bandul } \\
\text { atau liontin) }\end{array}$ \\
\hline $\begin{array}{l}\text { Agus Bin } \\
\text { Sutarso }\end{array}$ & $\begin{array}{l}\text { Reni Binti } \\
\text { Ngatiman }\end{array}$ & Rp.10.000.000,- & $\begin{array}{l}\text { Kalung emas } \\
5 \text { gram dan } \\
\text { gelang emas } \\
5 \text { gram }+ \\
\text { bseperangkat } \\
\text { pakaian }\end{array}$ \\
\hline Rois Bin Satip & $\begin{array}{l}\text { Sindi Binti } \\
\text { Winarto }\end{array}$ & Rp.10.000.000,- & $\begin{array}{l}\text { Kalung emas } 5 \\
\text { gram+ 1/2gram } \\
\text { liontin. Cincin } \\
\text { perak } 2 \text { gram }\end{array}$ \\
\hline $\begin{array}{l}\text { Warsito Bin } \\
\text { Darjo }\end{array}$ & $\begin{array}{l}\text { Tri Utami Binti } \\
\text { Paino }\end{array}$ & Rp.10.000.000,- & $\begin{array}{l}\text { Cincin } 5 \text { gram } \\
24 \text { krt. }\end{array}$ \\
\hline $\begin{array}{l}\text { Mustofa Bin } \\
\text { Supadi }\end{array}$ & $\begin{array}{l}\text { Murtini Binti } \\
\text { Rolimin }\end{array}$ & Rp.10.000.000,- & $\begin{array}{l}\text { Seperangkat } \\
\text { pakaian dan } \\
\text { kalung emas } 5 \\
\text { gram }\end{array}$ \\
\hline $\begin{array}{l}\text { Budi bin } \\
\text { Widodo }\end{array}$ & $\begin{array}{l}\text { Murniati Binti } \\
\text { Sutar }\end{array}$ & Rp.10.000.000,- & $\begin{array}{l}\text { Kalung emas } \\
5 \text { gram beserta } \\
\text { seperangkat } \\
\text { pakaian }\end{array}$ \\
\hline $\begin{array}{l}\text { Andri Bin } \\
\text { Sunaryo }\end{array}$ & $\begin{array}{l}\text { Tugiyati Binti } \\
\text { Slamet }\end{array}$ & Rp.10.000.000,- & $\begin{array}{l}\text { Tidak } \\
\text { disebutkan }\end{array}$ \\
\hline $\begin{array}{l}\text { Catur Bin } \\
\text { Suradi }\end{array}$ & $\begin{array}{l}\text { Astini Binti } \\
\text { Sularno }\end{array}$ & Rp.20.000.000,- & $\begin{array}{l}\text { Perhiasan } \\
\text { emas kalung, } \\
\text { cincin } 10 \text { gram } \\
+ \text { seperangkat } \\
\text { pakaian }\end{array}$ \\
\hline $\begin{array}{l}\text { Ahmad Arifin } \\
\text { Bin Soiman }\end{array}$ & $\begin{array}{l}\text { Nika Apriani } \\
\text { Binti Erianto }\end{array}$ & Rp.20.000.000,- & $\begin{array}{l}\text { Kalung Emas } \\
6 \text { Gram dan } \\
\text { seprangkat } \\
\text { pakaian }\end{array}$ \\
\hline $\begin{array}{l}\text { Parwanto Bin } \\
\text { Pendi }\end{array}$ & $\begin{array}{l}\text { Istimunawaroh } \\
\text { Binti mujilan }\end{array}$ & Rp.20.000.000,- & $\begin{array}{l}\text { Kalung Emas } \\
5 \text { gram dan } \\
\text { seprangkat } \\
\text { Pakaian }\end{array}$ \\
\hline
\end{tabular}




\begin{tabular}{|c|c|c|c|}
\hline Laki-Laki & Perempuan & $\begin{array}{l}\text { Nominal } \\
\text { Denda }\end{array}$ & Singsetan \\
\hline $\begin{array}{l}\text { Yuli Santoso } \\
\text { Bin Kuwatni }\end{array}$ & $\begin{array}{l}\text { Pita Puspitasari } \\
\text { Binti Prianto }\end{array}$ & Rp.20.000.000,- & $\begin{array}{l}\text { Kalung Emas } \\
10 \text { Gram }\end{array}$ \\
\hline $\begin{array}{l}\text { HeriBin } \\
\text { Waluyo }\end{array}$ & Lina Binti Tukino & Rp.20.000.000,- & $\begin{array}{l}\text { Kalung Emas } \\
5 \text { gram dan } \\
\text { seprangkat } \\
\text { pakaian }\end{array}$ \\
\hline $\begin{array}{l}\text { Jumardi Bin } \\
\text { Giyono }\end{array}$ & Rindi Binti Sadin & $\begin{array}{l}\text { Rp.20.000.000,- } \\
\text { ditambah 1/4 } \\
\text { Ha Ladang/ } \\
\text { Pekarangan }\end{array}$ & $\begin{array}{l}\text { KalungEmas } \\
5 \text { gram dan } \\
\text { seperangkat } \\
\text { Pakaian }\end{array}$ \\
\hline $\begin{array}{l}\text { Rendra } \\
\text { Pratama bin } \\
\text { Juwarso }\end{array}$ & $\begin{array}{l}\text { Trimulyaningsih } \\
\text { Binti Tumardi }\end{array}$ & Rp.20.000.000,- & $\begin{array}{l}\text { Tidak } \\
\text { disebutkan }\end{array}$ \\
\hline
\end{tabular}

Sumber: Arsip Surat PernyataanPerjanjian Khithbah

Surat perjanjian khithbah mencantumkan identitas masing-masing pihak beserta saksi-saksinya. Kedua belah pihak telah sepakat mengadakan perundingan atau pertunangan (Jw: peningsetan). Hal ini disaksikan oleh semua saksi yang ada, termasuk tokoh adat, tokoh agama, dan tokoh pemuda kampung. Kemudian, disepakati bersama bahwa berdasar peraturan adat Dusun VII Gaya Baru V, Kecamatan Bandar Surabaya,Kabupaten Lampung Tengah, terdapat ketentuan bahwa barang siapa di antara dua belah pihak, baik laki-laki maupun perempuan menggagalkan perundingan tersebut dikenakan sanksi/denda/peraturan adat Dusun VII, Gaya Baru V, Kecamatan Bandar Surabaya KabupatenLampung Tengah sebanyak Rp.........(sesuai tahun atau kesepakatan).

Bilapihak laki-laki yang membatalkan maka dikenakan sanksi atau denda / peraturan sebesar Rp......................... singsetan hilang atau tidak dikembalikan.Bila pihak perempuan membatalkan khitbah dikenakan sanksi/denda/peraturan sebesar Rp20.000.000 ditambah mengembalikan singsetan. Kemudian nominal tersebut dibagi ke dalam dua bagian: Rp 15.000.000,- untuk pihak yang dibatalkan dan Rp 5.000.000,untuk kas dusun atau kampung Gaya Baru V. 
Selama 2013-2015 terdapat satu perjajian khithbahyang telah dibatalkan yakni pasangan J bin $\mathrm{G}$ dengan $\mathrm{R}$ binti S.Menurut penuturan dari perwakilan keluarga besar, pembatalan dilakukan dari pihak laki-laki, karena pihakperempuan telah berpacaran dengan laki-laki lain ketika bekerja di luar Lampung.Pihak lakilaki enggan menikahinya karena perempuan telah berbuat addhukhul qabla zawaj dengan laki-laki lain. ${ }^{5}$

Secara psikologis, pihak keluarga yang membatalkan tidak mendapatkan masalahkarena jika memang pernikahan harus dilanjutkan justrumenjadi beban moralbagi keluarga laki-laki karenakesalahan dilakukan oleh pihak perempuan. Justru jika memang pernikahan dilanjutkan atau khithbah tidak dibatalkan akan menjadi beban moral bagi pihak laki-laki. Dan pihak perempuan juga tidak mau menerima sanksi denda karena pihak perempuan siap untuk dinikah, namun pihak laki-lakitetap tidak mau menikahinya. ${ }^{6}$

Karena pada periode 2013-2015 hanya terjadi satu pembatalan khithbah, penulis menambahkan sampel pembatalan khithbah pada tahun-tahun sebelumya. Ada beberapa kasus pembatalan khithbah di wilayah Kecamatan Bandar Surabaya Jogja V. Misalnya kasus (J M binti Is) yang membatalkan khithbah dengan alasan tidak cocok dengan sifat atau perilaku pihak lakilaki. Pembatalan dilakukan karena pihaklaki-laki (WN bin SMD) suka minum-minuman (khamr) dan menyinggung perasaan calon mertua. $^{7}$

Karena pembatalan dilakukan oleh pihak perempuan maka pihak laki-laki menuntutsanksi sesuai kesepakatan, Rp.2.500.000,Karena tidak terima dengan denda yang diterapkan, pihak perempuan mengajukan permohonan denda balik kepada pihak laki-laki, dengan alasan adanya perbuatan yang dilakukan di luar syar'iyangmerugikan pihak perempuan. ${ }^{8}$ Walaupun pada awalnya telah disepakati bersama, terkadang sanksi terasa berat.

${ }^{5}$ NM, Keluarga Saudara J bin G, 13 Februari 2016.

${ }^{6}$ Ibid.

${ }^{7}$ Ibid.

${ }^{8}$ Dalam forum persidangan bersama tetua kampung, diakui bahwa pihaknya melakukan dukhul qabla zawaj bersama pihak lain. 
Menyiasati hal tersebut, ada beberapa kasus pembatalan sanksi khithbah dengan menggunakan akad nikahsementara. Pernikahan tetap dilangsungkan tapi hanya untuk sementara, demi batalnya sanksi. Sebagian masyarakat menyebut pernikahan semacam ini dengan istilah bargodhongbaruwong. ${ }^{9}$

Kasus ini terjadi pada pasangan JK bin KR dengan RKM binti JN KMyang menikah pada Senin, 29 April2002. Pernikahan bar godhong bar uwong juga terjadi pada 18 April2002,SR bin TRdengan YLT bintiSPD.Setelah menikah, kedua mempelai langsung pisah ranjang, pulang ke rumah orangtua masingmasing.Hal ini terjadi karena sebelum akad nikah, YLT sudah tidak suka terhadap SR. Menurut penuturan tetua Murihono,SR merasa tertipu oleh YLT yangseusai resepsi YLT langsung pulang kerumah orang tuanya. ${ }^{10}$

Begitu pula di wilayah Seputih Surabaya ditemukan pasangan SB bin SK dengan MR bin Sl melakukan nikah bar godhong bar uwonguntuk menghindari denda, yang pada awalnya pihak laki-laki ingin membatalkan pinangan karena ia merasa tidak sekufu dengan si perempuan. SB ingin mengundurkan diri atau membatalkan pinangan atau khithbah, karena takut atau khawatir terlalu besarnya denda yang berupa banjar pekarangan maka ia melanjutkan sampai akad nikah guna menghindari jumlah denda yang sangat besar. ${ }^{11}$

\section{Analisis Hukum Islam terhadap Sanksi Pembatalan Khithbah}

\section{Nilai Penting Khithbah dalam Pernikahan}

Hakikat khithbah adalah ungkapan atau statemen pihak laki-laki kepada pihak perempuan dengan tujuan untuk menikahi wanita yang dipinang atau yang di-khithbah. Menurut Wahbah Zuhaili, mengungkapkan untuk menikah dengan seseorang tertentu

${ }^{9}$ Pernikahan bar ghodhong bar uwong dalam bahasa Jawamerupakan parikan atau sejenis pantun yang berarti, setelah semua sampah resepsi dibereskan, beres pula pernikahannya. Masing-masing mempelai kembali ke rumah orangtua masing-masing.

${ }^{10}$ Murihono, Anggota keluarga SR bin TR, 22 Januari 2016.

11 Nurdin, Tokoh Masyarakat Gaya Baru III, Seputih Surabaya, 10 Januari 2016. 
dan memberitahukan keinginan tersebut kepada perempuan tersebut dan walinya. ${ }^{12}$ Esensi dari peminangan merupakan tahap prapernikahan sebagai bentuk permohonan atau persetujuan menuju pernikahan. Abdullah Sidik berpendapat bahwa peminangan adalah menyampaikan permintaan oleh calon suami kepada calon Istri untuk memperistri calon Istri tersebut dengan cara yang sudahdikenal di masyarakat. ${ }^{13}$

Al-Hamdanimenyatakanbahwa tradisikhithbahmerupakan kebiasaan Arab lama yang diteruskan dan direvitalisasi oleh Islam. Meminang dilakukan sebelum terjadinya akad nikah dan setelah dipilih secara seksama sebelum akad nikah, agar masingmasing pasangan saling mengenal sehingga perkawinan nanti benar-benar berdasarkan pandangan dan penilaian yang jelas. ${ }^{14}$

Zahri Hamid menyatakan bahwa meminang maksudnya adalah seorang laki-laki meminta kepada seorang perempuan untuk menjadi istrinya, dengan cara-cara yang sudah umum berlaku di masyarakat dengan maksud usaha pendahuluan dalam perkawinan. Masaikatan untuk melangsungkan perkawinaninilah yang disebut dengan khithbah. Dalam masa ini antara laki-laki dan perempuan belum boleh bergaul layaknya suami istri, karena khithbah bukanlah perkawinan.

Dalam peminangan diperbolehkan menggunakan menggunakan kata-kata yang jelas (terang) atau dengan sindiran, sebagaimana dalam Tafsir Jalalain surat al-Baqarah: 235 pada kalimat "Alimallahuannakum satadzkuruunahunna "(Allah mengetahui bahwa kamu akan menyebut-menyebut mereka) dan tidak sabar untuk meminang maka diperbolehkannya secara sindiran. ${ }^{15}$ Khithbah merupakan permintaan pihak peminangkepada pihak yang dipinang agar bersedia menikah

\footnotetext{
${ }^{12}$ Wahbah Zuhaili, Al-Figh al-Islâmī wa Adillatuhu (Beirut: Dar al-Fikr, 1997), 20-21.

${ }^{13}$ Abd Shomad, Hukum Islam Penormaan Prinsip Syariah Dalam Hukum Indonesia, (Jakarta: Kencana, 2012), 273.

${ }^{14}$ Ibid.

15 Imam Jalaluddin Al-Mahalli dan Jalaluddin Imam As-Suyuthi, Terjemahan Tafsir Jalalain Berikut Asbabun Nuzul, vol. 2 (Bandung: Sinar Baru Algensindo, 2009), 128.
} 
dengannya, yang merupakan babak awal pernikahan menurut syara' maupun adat.

Tujuan pinangan adalah agar yang meminang dan yang dipinang saling mengenal, yakni sebagai persiapan memasuki rumah tangga yang langgeng, mewujudkan rasa saling pengertian dan keharmonisan, sesuai tatanan yang ditetapkan ajaran Islam. ${ }^{16}$ Jika melihat pengertian di atas bahwa persiapan khithbah merupakan persiapan yang cukup matang sebelum menjatuhkan pilihan calon pendamping hidup, sikap kehatian-kehatian tersirat dalam arti khithbah itu sendiri.

Secara umum dapat diartikan seorang laki-laki menampakan kecintaannya untuk menikahi seorang wanita yang halal dinikahinya secara syara'. Adapun pelaksanaannya beragam, adakalanya peminang itu sendiri yang meminta langsung kepada yang bersangkutan, atau melalui keluarga, atau melalui utusan seseorang yang dapat dipercaya untuk meminta orang yang dikehendaki. ${ }^{17}$ Keadaan ini telah membudaya di tengah masyarakat dan dilaksanakan sesuai dengan tradisi masyarakat setempat.

\section{Perspektif Tokoh Masyarakat}

Dalam praktiknya, pembatalan khithbah yang dilakukan sebagian masyarakat Bandar Surabaya dan Seputih Surabaya dilakukan dengan menerapkan denda matriil. Seorang tokoh kampung, Ali Muhtar, S.Ag. M.Sy, menyatakan bahwa ia sepakat dengan sanksi pembatalan khithbah. Baginya, khithbah merupakan bentuk perikatan atau pertalian yang mana selangkah lagi menuju jenjang pernikahan, maka jika terjadi pembatalan, hal tersebutakan menjadi beban moral atau pukulan berat bagi pihak yang dibatalkan. Adapun sanksi atau denda tergantung kesepakatandan hal tersebut sebagai upaya membuat jera, agar

${ }^{16}$ Wahbah Zuhaili, Fiqih Imam Syafi'i: Mengupas Masalah Fiqhiyah Berdasarkan Al-Qur" an dan Hadits, terj, trans. oleh Muhammad Afifi dan Abdul Hafiz (Jakarta: Almahira, 2010), 472.

${ }^{17}$ Abdul Aziz Muhammad Azzam dan Abdul Wahab Sayyed Hawwas, Figh Munakahat (Khitbah, Nikah dan Talak), trans. oleh Abdul Majid Khon (Jakarta: Amzah, 2009), 8. 
orang tidak begitu mudah membatalkan pinangan. ${ }^{18}$

Sementara itu, tokoh agama, A. Muhaiminmenyatakan sepakat dengan perjanjian khithbah. Namunbila dihubungkan dengan akad nikah terkadang menjadi sebuah kendala, yaitu memunculkan unsur keterpaksaan dalam pernikahan, sehingga terjadilah "nikah bohongan"19 sebagaimana pasangan SK bin TR dengan YLT binti SPR. ${ }^{20}$ Tokoh kampung Ahmad Panut menyatakan bahwa secara prinsipil ia setuju, karena sudah disepakati para tetua kampung dan tokoh-tokoh masyarakat. Tujuan yang ingin dicapai supaya orang tidak sembarangan membatalkan pinangan. Jika memang terjadi pembatalan khithbah, hal tersebut dimaknai sebagai "bukan jodoh". ${ }^{21}$

Dari pendapat diatas para tokoh masyarakatsetuju dengan adanyaadanya sanksi pembatalan, akan tetapi jika beban sanksi yang cukup besar juga akan memunculkan permasalahan baru, yakni akanmempengaruhi atau merusak tujuan dari pernikahan itu itu sendiri dengan adanya akad nikah bar godhong bar uwong. Hal ini tentu saja kontradiktif dengan tujuan pensyariatan nikah dalam Islam.

\section{Perspektif Kompilasi Hukum Islam (KHI)}

Seringkali, pihak laki yang mengajukan pinangan kepada pihak perempuan. Meskipun demikian, adakalanya pihak perempuan mengajukan pinangan terhadap pihaklaki-laki. ${ }^{22}$ DikampungGaya Baru 5, Bandar Surabaya maupun kampung Gaya Baru 3, Seputih Surabaya,pihak yang melakukan peminangan biasanya pihak laki-laki yang kemudian memberikan hadiah singsetanberupa cincin, gelang, ataukalungkepada pihak perempuan sebagai tanda jadi khithbah atau pertunangan. ${ }^{23}$

${ }^{18}$ Ali Muhtar, Ketua KUA Bandar Surabaya, 3 Februari 2016.

19 Nikah bohongan, di depan publik telah menikah namun secara hati mereka tidak ingin menikah. Menikah dengan tujuan untuk langsung cerai dengan tujuan menghindari jeratan denda atau sanksi.

${ }_{20}$ Ahmad Muhaimin, Tokoh Agama Seputih Surabaya dan Bandar Surabaya, 22 Januari 2016.

${ }^{21}$ Ahmad Panut, Tokoh Agama Bandar Surabaya, 22 Januari 2016.

${ }^{22}$ Mukhtar Kamal, Asas-Asas Hukum Islam Tentang Perkawinan (Jakarta: Bulan Bintang, 1993), 33.

23 Budaya seperti ini sudah turun-temurun di Dusun Jogja 5 dan Jogja 
Dalam pertunangan inilah, peraturan kampung diberlakukan sebagaimana dalam format yang telah mereka berlakukan. $^{24}$ Besarnya hadiah yang diberikan tergantung kemampuan pihak laki-laki dan tersebut tidak ditentukan kadarnya. Masyarakat setempat sering menyebut dengan istilah peningset atau singsetan yang mengikat dua belah pihak. ${ }^{25}$ Karena peminangan merupakan pendahuluan perkawinan yang disyariatkan sebelum ada ikatan suami-istri dengan tujuan agar waktu memasuki perkawinan didasari kerelaan yang didapatkan dari penelitian, pengetahuan, serta kesadaran masingmasing pihak. ${ }^{26}$

Pengertian tersebut sejalan dengan pengertian yang terdapat dalam Kompilasi Hukum Islam (KHI) pasal 1 huruf (a) Peminangan ialah kegiatan upaya ke arah terjadinya hubungan perjodohan dari seorang laki-laki kepada seorang perempuan atau sebaliknya dengan perantara seorang yang dipercaya. ${ }^{27}$ Secara ringkas khithbah merupakan bentuk pernyataan seorang laki-laki kepada seorang perempuan atau walinya dengan tujuan menikah dengan mempertimbangkan berbagai aspek, agar setelah melangsungkan pernikahan tidak ada kekecewaan atau penyesalan di kemudian hari dan terbentuknya ikatan yang kuat (mitsaqon gholidzan) menuju cita-cita dunia maupun akhirat.

Ikatan perkawinan merupakan suatu ikatan yang sakral, yakni merupakan bentuk perjanjian suci antara seorang pria dengan seorang wanita. Selain memiliki ikatan suci, perkawinan juga mempunyai nilai perdata perkawinan memiliki beberapa asas, di antaranya: kesukarelaan, persetujuan kedua belah pihak, kebebasan memilih, kemitraan suami-istri, untuk selama-

19 Bandar Surabaya dan Seputih Surabaya.

24 "Arsip Surat Perjanjian Khithbah di Gaya Baru 5, Bandar Surabaya."

${ }^{25}$ Sri Mintosih, Pandangan Generasi Muda terhadap Perkawinan Adat di Kota Surabaya (Surabaya: Depdikbud, 1998), 33.

${ }^{26}$ M. Ahmad Tihami dan Sohari Sahrani, Fikih Munakahat: Kajian Fikih Nikah Lengkap (Jakarta: Rajawali, 2009), 24.

${ }^{27}$ Tim Redaksi Fokusmedia, Kompilasi Hukum Islam (Bandung: Fokusmedia, 2007), 6. 
lamanya, dan monogami terbuka (kondisi dharuriyah). ${ }^{28}$ Sanksi pembatalan khithbah belumlah diatur secara spesifik namun Kompilasi Hukum Islam (KHI) pasal 13 ayat (1) mengatur:

(1) Pinangan belum menimbulkan akibat hukum dan para pihak bebas memutuskan hubungan peminangan.

Kemudian ayat (2) menyatakan:

(2) Kebebasan memutuskan hubungan peminangan dilakukan dengan tata cara yang baik sesuai tuntunan agama dan kebiasaan setempat, sehingga tetap terbina kerukunan dan saling menghargai. ${ }^{29}$

Jika menengok pasal 13 ayat (1) di atas, maka pembatalan khithbah belum menimbulkan sanksi apapun. Akan tetapi, pasal 13 ayat (2) menegaskan bahwa kebebasan memutuskan hubungan peminangan dilakukan dengan tata cara yang baik sesuai dengan tuntunanagama dan kebiasaan setempat. Maka praktik yang sudah berlaku di Gaya Baru 3 dan Gaya Baru 5 tentang perjanjian khithbah beserta aturan sanksinya bisa dikatakan selaras dengan hukum Islam, setidak-tidaknya tidak bertentangan dengan Kompilasi Hukum Islam.

Hal ini karena tujuan diadakannya peraturan tersebut adalah untuk menjamin serta menjaga kerukunan dan rasa saling menghargai di antara kedua belah pihak. Selama ini, dalam pengamatan penulis, keberadaan perjanjian khithbah tersebut relatif mampu menjaga nilai-nilai yang diamanatkan oleh $\mathrm{KHI}$ dalam pasa 13 ayat (2) di atas.

\section{Pembatalan Khithbah Perspektif Ulama Mazhab}

Di kalangan ulama madzhab malikiyahterdapat pendapat populer bahwa hadiah yang diberikan sebelum akad nikah atau dalam proses akad dibagi antara pihak perempuan dan pihak laki-laki. Jika pembatalan khithbah dilakukan oleh pihak lelaki maka ia tidak berhakmeminta kembali sedikitpun. Akan tetapi

${ }^{28}$ Muhammad Daud Ali, Hukum Islam: Pengantar Ilmu Hukum dan Tata Hukum Islam di Indonesia (Jakarta: Rajagrafindo, 2001), 136.

${ }^{29}$ Fokusmedia, Kompilasi Hukum Islam, 9-10. 
jika pembatalantersebut dari pihak perempuan maka si lelaki boleh meminta kembali hadiah-hadiah yang telah diberikan. Jika akad tidak terjadi, maka si pemberi boleh meminta hadiahnya kembali atau semisalnya. ${ }^{30}$

Seseorang yang telah melakukan khithbah pada hakikatnya telah memiliki maksud dan tujuan untuk menikah, namun dalam perjalanannya menuju pintu gerbang pernikahan adakalanya terjadi pembatalan peminangan. Dalam hal ini Imam Daud berpendapat bahwa pernikahan yang terjadi dalam pinangan orang lain dapat dibubarkan. Maksud dari pendapat ini bahwa meminang diatas pinangan orang lain tidak diperbolehkan. Jika pinangan kedua ini sampai pada akad nikah, maka akad ini dapat dibubarkan.

Terhadap perkawinan atas perempuan yang sedang dipinang oleh orang lain, Imam Malik memiliki dua pendapat, yaitu boleh dibubarkan dan tidak boleh dibubarkan. ${ }^{31}$ Imam Malik berpendapat bahwapernikahan dapat dibubarkan sebelum terjadinya hubungan intim suami-istri. Jika sudah terjadi hubungan suami-istri, maka perkawinan tidakdapat dibubarkan. ${ }^{32}$ Perbedaan dua pendapat Imam Malik ini pada posisipembubaran akad yakni antara qabla ad-dhukhul dan ba'da ad-dhukhul.

Seseorang dilarang meng-khithbah orang yang sedang dikhithbah oleh orang lain, meskpun khithbah pertama ini belum mendapatkan jawaban. Demikian juga jika pelamar pertama tidak memberikan persetujuan bagi masuknya pelamar kedua. Hal ini dilarang karena berpotensi menimbulkan permusuhan dan menyakiti pelamar pertama. Jika salah satu pihak baik pelamar pertama atau pihak yang dilamar mengizinkan masuknya pelamar kedua, maka pelamar kedua diperbolehkan mengajukan lamaran. Kebolehan lamaran kedua ini juga berlaku ketika lamaran pertama sudah dibatalkan.

Kemudian, jika khithbah pertama belum selesai atau masih dimusyawarahkan atau dalam kondisi ragu-ragu, maka pendapat

\footnotetext{
${ }^{30}$ Zuhaili, Al-Figh al-Islâmī wa Adillatuhu, 37.

${ }^{31}$ Imam An-Nawawi, Syarah Shahih Muslim (Jakarta: Pustaka Azzam, 2011), 560 .

${ }^{32}$ Ibid.
} 
yang paling benar adalah tidak diharamkan untuk melakukan khithbah kedua. Akan tetapi menurut Madzhab Hanafi khithbah kedua hukumnya makruh. Hukum ini merujuk atas keumuman hadist-hadist tentang larangan mengkhithbah perempuan yang telah dikhithbah oleh orang lain. ${ }^{33}$

Terhadap aturan pengembalian singsetan atau hadiah khithbah yang terapkansebagian masyarakat Seputih Surabaya dan Bandar Surabaya, hal ini ada kesesuaiandengan pendapatdi kalangan Malikiah. Akan tetapi, pendapat Malikiah menerapkan prinsip pihak mana yang membatalkan khithbah, bukan pihak mana yang menyebabkan pembatalan khithbah.

Pendapat Malikiahselaras dengan pendapat Abu Hanifah. Baginya, hadiah khithbah merupakan pemberian. Ketika khithbah dibatalkan oleh perempuan, maka lelaki berhak untuk meminta kembali pemberiannya, terkecuali adanya hal yang mencegahnya seperti rusak, kwalitasnya menurun, atau terjadi pernikahan. Jika barang yang diberikan oleh pihak laki-laki masih ada maka ia boleh memintanya. ${ }^{34}$ Namun jika barang-barang yang telah diberikan rusak atau kadarnya menurun atau terjadi perubahan, cincin hilang, kain telah dibikin baju, makalelaki yang pengkhithbah tidak bisa meminta gantinya.

Pendapat inisecara implisit mensinyalir, jika barang atau hadiah yang diberikan masih ada dan belum rusak maka pihak pemberi boleh meminta kembali.Di sini terdapat kebolehanpembebanan sanksikepada perempuan yang membatalkan khithbah dengan mengembalikan singsetan. Akan tetapi jika barang tersebut sudah rusak ia syaratkanmeminta kembali atas barang tersebut. Dua pendapat di atas tidakmensyaratkan sanksi (berupa denda materiil atau uang), yakni hanya sebatas pengembalian hadiah khithbah.

Sementara itu, ulama mazhab Malikiyah berpendapat bahwa jika pengkhithbah memberi atau membelanjakan sesuatu kepada yang dikhithbah, kemudian ternyata yang dikhithbah menikah dengan orang lain, menurut pendapat

${ }^{33}$ Zuhaili, Al-Fiqh al-Islâmī wa Adillatuhu, 22.

${ }^{34}$ Ibid., 37. 
yang terkuat, pengkhithbah berhak meminta kembali apa yang diberikannya, kecuali jika adat atau syarat (perjanjian tertentu) menuntut hal yang berbeda. Pendapat Malikiah membolehkan adanya adat dan syarat atauperjanjian khithbah yang dibuat oleh masyarakat sepanjang tidak bertentangan dengan syara'.

Ulama Hanabilahberpendapat bahwa sebelum akad nikah, si lelaki boleh meminta hadiahnya kembali atau dikembalikan. Pendapat ini mensyaratkan kebolehan meminta atau mengembalikan sampai batas terjadinya akad nikah. Hanabilah memberikan gambaran bahwa pembatalan khithbah dilakukan oleh pihak perempuan disyaratkan untuk mengembalikanhadiah khithbah atau pinangan. Hanabillah juga tidak mensyaratkan adanya sanksi diluar hadiah khithbah. Tidak adanya sanksi materiil selain hadiah khithbah. Jika melihat teks pernyataan atau perjanjian yang dibuat sebagian masyarakat Seputih Surabaya dan Bandar Surabaya maka lebih mendekati kepada pendapat Malikiah.

Dalam praktik di Gaya Baru 3 dan Gaya Baru 5, bila pihak perempuan yang membatalkan khithbah, maka pihak perempuan dikenakan sanksi/denda/peraturan sesuai kesepakatan ditambah mengembalikan peningset. Jika dilihat dari sisi kesepakatan perjanjian, hal tersebut bisa dibenarkankarena dalam mengadakan aqadyakni adanya iradah al-aqdiyah: yang pertama yaitu menyangkutkeinginan batin (niat atau maksud) keinginan batin dapat terwujud dengan adanya kondisi bebas (ikhtiyar). Ulama Hanafiyah berpendapatbahwa iradah dan ikhtiyar adalah sama. ${ }^{35}$

Keinginan kedua yaitu keinginan zahir, dimana zahir merupakan bentuk formula dari keinginan batin, sehingga keinginan zahir dan batinakad dapat dinyatakan sah. ${ }^{36}$ Dari teori akad timbullah suatu hukum perikatan atau perjanjian dimana kesepakatan tidak dapatdibatalkan secara sepihak, kalaupun dibatalkan harus berdasarkan kesepakatan dari kedua belah pihak. ${ }^{37}$ Walaupun akad terkadang merupakan kesepakatan yang

${ }^{35}$ Rahmad Syafi' i, Fiqih Muamalah (Bandung: Pustaka Setia, 2000), 64.

${ }^{36}$ Ibid.

${ }^{37}$ Chairuman Pasaribu dan Suhrawardi K. Lubis, Hukum Perjanjian dalam Islam, 3 ed. (Jakarta: Sinar Grafika, 1996), 28. 
diakadkan, akan tetapi jika dinilai dariisiperjanjian, tetap tidak dapat dibenarkan karena tidak ada denda materiil dalam khithbah kecuali hanya sebatas mengganti hadiah khithbah. Isyarat yang diberikan oleh Malikiah adanya adat dan syarat adalah merupakan kebolehan sebatas akad perjanjian saja, sebagaipenguat dalam khithbah.

Ulama Syafi'iyah berpandangan bahwa si lelaki boleh meminta kembali hadiah khithbah yang telah diberikan, dengan alasan memberi itu hanya untuk menikahi perempuan tersebut. Jika hadiah tersebut masih ada maka ia boleh memintanya kembali.Jika hadiah tersebut sudah rusak maka ia boleh meminta gantinya. ${ }^{38}$ Sanksi meminta kembali hadiah khithbah bagi laki-laki menurut Syafiiyah sangat disyaratkan. Alasan Syafi'iyah sangat jelas karena khithbah tiada lain hanya untuk menikah. Akan tetapi sanksi tetap hanya sebatas hadiah yang diberikan, tidak boleh ada denda materi lain.

Sebagai bahan pembanding, Mahkamah Mesir pada 1938 memutuskan bahwa khithbah bukan merupakan suatu harus dilakukan, sekadar membatalkan khithbah bukanlah merupakan suatu sebab yang mewajibkan untuk lahirnya ganti rugi.Jika pembatalan khithbah dibarengi dengan suatu tindakan yang merugikan salah satu pihak maka berlakulah hukum ganti rugi, yakni berlandaskan atas keteledoran atau kesalahan yang menyebabkan kerugian bagi orang lain. ${ }^{39}$

Berdasarkan hal tersebut maka ada dua hal yang berbeda: Jika pihak yang membatalkan telah menimbulkan kerugian,maka boleh meminta ganti rugi karena pembatalankhithbah. Kedua,jika pihak yang membatalkan tidak menimbulkan kerugian pihak lain maka tidak dikenakan ganti rugi karena tidak didapati adanya unsur penipuan. ${ }^{40}$ Menurut penulis karena khithbah bukanlah suatu yang wajib, maka peraturan - peraturan yang dibuat oleh sebagian masyarakatLampung Tengahmerupakan peraturan yang sangat memberatkankarena besarnya sanksi yang telah diterapkan.

\footnotetext{
${ }^{38}$ Ibid.

${ }^{39}$ Zuhaili, Al-Figh al-Islâmī wa Adillatuhu, 38.

${ }^{40}$ Ibid.
} 
Sementara itu, Undang-Undang Maroko mengambil pendapat ulama Malikiyah.Yordania mengambil pendapat Hanafi dan secara tegas menerapkan hukum hadiah-hadiah khithbah sesuai hukum pemberian. Demikian juga dengan UndangUndang Syiria yang menerapkan mazhab Hanafi. Dalampasal 305 tertulis bahwa: Setiap hal yang tidak tercantum dalamteks perundang- undangan ini maka dirujuk ke pendapat yang paling kuat di dalam madzhab hanafi. Demikian pula dalam pasal 4 dikatakan bahwa hukum hadiah disesuaikan dengan hukum pemberian. $^{41}$

Tabel 2. Pendapat ulama madzhab tentang pembatalan khithbah dan sanksinya

\begin{tabular}{|c|c|c|c|}
\hline Pendapat & $\begin{array}{l}\text { Status Hadiah } \\
\text { Khithbah }\end{array}$ & $\begin{array}{c}\text { Pihak Yang } \\
\text { Membatalkan } \\
\text { Khithbah }\end{array}$ & Sanksi Khithbah \\
\hline $\begin{array}{c}\text { Ulama } \\
\text { Abu Hanifah }\end{array}$ & $\begin{array}{l}\text { Merupakan } \\
\text { pemberian }\end{array}$ & Perempuan & $\begin{array}{l}\text { Pihak laki-laki } \\
\text { punya hak untuk } \\
\text { menarik kembali } \\
\text { hadiah khithbah, } \\
\text { jika belum rusak. }\end{array}$ \\
\hline $\begin{array}{c}\text { Ulama } \\
\text { Malikiyah }\end{array}$ & $\begin{array}{l}\text { Sebagai } \\
\text { hadiah } \\
\text { sebelum } \\
\text { akadnikah }\end{array}$ & $\begin{array}{l}\text { Laki-laki } \\
\text { Perempuan }\end{array}$ & $\begin{array}{l}\text { Tidak berhak } \\
\text { menarik } \\
\text { hadiahkhithbah. } \\
\text { Laki-laki boleh } \\
\text { menarik hadiahya, } \\
\text { walaupun } \\
\text { sudah tiada } \\
\text { atau rusak tetap } \\
\text { disyaratkanuntuk } \\
\text { mengganti kecuali } \\
\text { (adanya syarat dan } \\
\text { adat) }\end{array}$ \\
\hline
\end{tabular}

${ }^{41}$ Ibid., 37. 


\begin{tabular}{cccl}
\hline Pendapat & $\begin{array}{c}\text { Status Hadiah } \\
\text { Khithbah }\end{array}$ & $\begin{array}{c}\text { Pihak Yang } \\
\text { Membatalkan } \\
\text { Khithbah }\end{array}$ & Sanksi Khithbah \\
\hline $\begin{array}{c}\text { Ulama } \\
\text { Hanabillah }\end{array}$ & Hadiah & $\begin{array}{c}\text { Pihak laki- } \\
\text { laki maupun } \\
\text { perempuan }\end{array}$ & $\begin{array}{l}\text { Hadiah } \\
\text { dikembalikan } \\
\text { sebelum akad } \\
\text { nikah (pernikahan } \\
\text { dengan orang } \\
\text { lain). }\end{array}$ \\
& & & \\
\hline Ulama & $\begin{array}{l}\text { Memberi } \\
\text { hadiah }\end{array}$ & Perempuan & $\begin{array}{l}\text { Boleh meminta } \\
\text { kembali danjika } \\
\text { hanyak untuk }\end{array}$ \\
& menikah & & $\begin{array}{l}\text { rusak di syaratkan } \\
\text { untuk mengganti. }\end{array}$ \\
\hline
\end{tabular}

\section{Denda Materi Tambahan atas Pembatalan Khithbah}

Dari empat madzab, hanya Malikiah yang berpendapat adanya adat dan syarat dalam ketentuan pembatalan khithbah nikah. Pendapat yang lain berpendapat bahwa sanksi pengembalian pinangan hanya sebatas hadiah khithbah. Dalam penjelasan lain, bila seseorang melamar wanita, kemudian ia mengirim atau memberi sejumlah uang atau barang kepadanya sebelum akad nikah tanpa disyarati apapun, dan tidak memberi maksud secara cuma-cuma, kemudian terdapat tidak kemauan menikah dari pihak wanita ataupun pihak laki-laki itu, maka si lelaki boleh mengambil pemberian tersebut. Seandainya lelaki tersebut memberikan harta, lalu wanita mengklaimnya sebagai hadiah, sementara si lelaki menyatakan sebagai mahar, maka si lelakilah yang dibenarkan jika bersedia bersumpah. ${ }^{42}$

Secara umum sanksi dalam masyarakat terkadang terbentuk dengan menggunakan dalih maslahah mursalah, seperti halnya perjanjian pembatalan sanksi khithbah.Sanksi pembatalan khithbahdisandarkan pada maslahah mursalah. Dalam hal ini para ulama memberikan persyaratan bahwa kemaslahatan harus

${ }^{42}$ Sahal Mahfudh, Solusi Problematika Aktual Hukum Islam Keputusan Muktamar, Munas, dan Konbes Nahdlatul Ulama (1926-2004 M) (Surabaya: Khalista, 2007), 439. 
selaras dengan dalil syara', tidak menuruti hawanafsu, rasional, memenuhi maqasid as-syari'ah, bersifat universal, dan memiliki common value.Menurut MudhofirAbdullah maslahah seperti inilah yang dapatdijadikan sebagai hujjahatau basis argumen pengambilan hukum. ${ }^{43}$

Meski demikian, dalam praktik yang terjadi di Gaya Baru 3 maupun di Gaya Baru 5, terdapat praktik penerapan denda materi dengan nominal yang sangat besar, misalnya Rp 20 juta atau rumah beserta isi dan pekarangannya, atau tanah ladang seperempat hektar. Nominal ini sulit diterima oleh akal sehat dan tentu saja akan memberatkan para pihak. Hal ini membuat banyak pengkhitbah berupaya melakukan hillah hukum atau upaya menghindari hukum. Salah satu caranya adalah dengan melakukan akad nikah bohongan. Hal ini dipraktikkan oleh pasangan SK bin TR dengan YLT binti SPR, pasangan JK bin KR dengan RKM bintiJN. ${ }^{44}$

Tentu saja, praktik nikah bohongan seperti ini tidak dapat dibenarkan, karena identik dengan nikah mut'ah walaupun dalam akad tidak muncul klausul kontrak. Sedangkan hukum nikah mut'ah adalah bathil. ${ }^{45}$ Hal ini dalam justru membuat maslahah yang ingin dipegang malah terlepas. Yang terjadi justru adalah mafsadat, karena nikah yang diselenggarakan tidak dilakukan untuk mencapai maslahat dan maqashid syariah. Sebaliknya, nikah diselenggarakan hanya untuk menjadi dalih menghindari denda.

Dari sini kita bisa menyatakan bahwa denda yang cukup fantastis tidak dapat dibenarkan. Terlebih terkadang terdapatadanya kebohongan pribadi dan publik dalam acara pernikahan bohongan yang dilakukan oleh masyarakat. Hal tersebut sudah cukup jelas menyelisihi nilaimaslahah dan mengundang nilai mafsadah. Secara fiqihpun yang dimaksudkan oleh Malikiahtentang syarat dan urftentunya bukanlah perkara yang memunculkan permasalahan yang mengundang mafsadah, menjauhkan darimaqasid asy- syari'ah. Para ulama yang

${ }^{43}$ Mudhofir Abdullah, Masail al-Fiqhiyyah: Isu-Isu Fikih Kontemporer (Yogyakarta: Teras, 2011), 121.

${ }^{44}$ Murihono, Anggota keluarga SR bin TR.

${ }^{45}$ Zuhaili, Fiqih Imam Syafi" i, 510. 
mengamalkan 'urf itu dalam memahami dan mengistibathkan hukum, menetapkan beberapa persyaratan untuk menerima 'urf tersebut, yaitu: ${ }^{46}$

a. 'Adat atau 'urf itu bernilai maslahat dan dapat diterima akal sehat;

b. 'Adat atau 'urf itu berlaku umum dan merata di kalangan orang-orang yang berada dalam lingkungan adat itu, atau di kalangan sebagian besar warganya;

c. 'Urf yang dijadikan sandaran dalam penetapan hukum itu telah ada (berlaku) pada saat itu sebelum penetapan hukum;

d. 'Adat tidak bertentangan dan melalaikan dalil syara' yang ada atau bertentangan dengan prinsip yang pasti.

Melihat ketentuan urf dan syarat yang dimaksudkan oleh Malikiah tentunya tidak berseberangan dengan ketentuan di atas. Kesepakatan perjanjian khithbah yang dibangun masyarakat Seputih Surabaya dan Bandar Surabayawalaupun ada kesesuaian antara pendapat Malikiah dan Hanabilah akan tetapi dalam pembebanan sanksi khithbah yang cukup besar belum dapat dibenarkan secara syara' karena masih terdapat banyaknya mafsadah yang ditimbulkan dari hukum perikatan dan perjanjian meskipun dibuat atas kesepakatan bersama. Hal tersebut terbukti adanya aqad pernikahan yang hanya untuk menghindari sanksi atau denda, dengan bukti adanya penahananbukti surat nikah oleh aparatur kampung setempat.

\section{Pihak Penyebab Pembatalan Khithbah vs Pihak Pembatal Khithbah}

Terdapat satu kasus yang menarik untuk dikaji lebih lanjut. Ada pula pembatalan khithbahsehingga gagal menikah.Pihak perempuan, JM binti Is,membatalkan khithbahdengan alasan tidak cocok dengan sifat atau perilaku si laki-laki. Pihaklakilaki, WN bin SMD,diketahui suka minum-minuman keras dan

${ }^{46}$ Abdul Wahhab Khallaf, Ilmu Ushul Fikih Kaidah Hukum Islam, trans. oleh Faiz el Muttaqien (Jakarta: Pustaka Amani, 2003), 117-18. 
menyinggung perasaan calon mertua. ${ }^{47}$

Karena pihak perempuan yang membatalkan, maka ia dikenakan sanksi/denda Rp. 2.500.000,-ditambah mengembalikan peningset. ${ }^{48}$ Pihak perempuan tidak terima dikenakan denda dan bahkan balik menuntut pihak laki-laki karena pihak lelakilah yang menyebabkan muncul keinginan membatalkan khithbah, lantaran adanya perbuatan si lelaki yang melanggar ketentuan syariat dan berpotensi merugikan pihak perempuan.

Kasus serupa juga terjadi dengan khithbah antara J bin G dengan Rnd binti Snd di Dusun Jogja 5. Pihak J bin G membatalkan khithbah dengan alasan Rnd berpacaran dengan lelaki lain dan sudah melakukan hubungan suami-istri dengan lelaki lain. Hal ini kemudian membuat J bin $G$ membatalkan khithbah. Atas pembatalan ini, J bin G dikenakan sanksi yang besar sesuai kesepakatan awal. Namun, pihak J bin G tidak mau membayar denda karena merasa tidak bersalah, lantaran pihak perempuanlah yang menyebabkan munculnya pembatalan khithbah.

Pihak Rnd binti Snd pun tidak mau membayar denda karena ia sudah mengakui kesalahan, meminta maaf, dan siap melangsungkan pernikahan. Rnd binti Snd beralasan bahwa yang membatalkan khitbah adalah pihak lelaki, bukan pihaknya. Maka mau tidak mau, pihak lelakilah yang harus membayarkan dendanya. Kedua belah pihak sama-sama ngotot.

Menghadapi persoalan semacam ini para tokoh dan pemuka masyarakat bingung dalam memutuskan siapa yang akan dikenakan sanksi. Karena pembatalan dilakukan oleh pihak A akan tetapi kesalahan dari pihak B.Sampai pada akhirnya para tokoh memutuskan bahwa pertunangan dibatalkan dan tidak ada pihak yang dikenakan sanksi denda. Meski demikian, pihak perempuan diminta untuk mengembalikan hadiah pinangan. ${ }^{49}$

Bila kita telaah lebih lanjut, implementasi denda khithbahdi Gayabaru 3 dan Gaya Baru 5 tersebut masih jauh dari harapan yang tersirat dalam KHI pasal 13 ayat 2: Kebebasan memutuskan

\footnotetext{
${ }^{47}$ Marfi, Tokoh Pemuda Kampung Gaya Baru 5, 22 Januari 2016.

48 "Arsip Surat Perjanjian Khithbah di Gaya Baru 5, Bandar Surabaya."

${ }^{49}$ Marfi, Tokoh Pemuda Kampung Gaya Baru 5.
} 
hubungan peminangan dilakukan dengan tata cara yang baik sesuai tuntunan agama dan kebiasaan setempat, sehingga tetap terbina kerukunan dan saling menghargai. ${ }^{50}$ Karena faktanya, penerapan sanksi yang terlampau besar dan kurang rigitnya diktum perjanjian justru memantik persoalan baru yang tak kalah pelik dan bahkan cenderung mengandung unsur mafsadat.

\section{Simpulan}

Secara umum, khithbah dihadirkan sebagai media perantara atau awalan menuju jenjang pernikahan yang lebih serius. Mengingat pentingnya prosesi tersebut, maka para pihak dituntut untuk tidak melakukan tindakan yang menodai khitbah tersebut, karena menciderai khitbah berpotensi merugikan salah satu pihak. Oleh sebab itulah, penerapan perjanjian khithbah oleh masyarakat di Gaya Baru 3 dan Gaya Baru 5 bisa dibenarkan secara syariat. Seluruh ulama menyatakan tidak ada masalah dalam hal ini. Hal ini utamanya mengacu pada argumen maslahat mursalah.

Meskipun demikian, terjadi problem ketika sanksi yang diterapkan terlampau tinggi sehingga menyulitkan para pihak. Kesulitan ini menyebabkan para pihak melakukan hal-hal hillah yang justru menodai kesucian pernikahan dan merusak maqashid pernikahan. Misalnya, dengan melakukan akad nikah bohongan demi menghindari denda. Hal ini tentu saja bertentangan dengan syariat.

\section{Daftar Pustaka}

Abdullah, Mudhofir. Masail al-Fiqhiyyah: Isu-Isu Fikih Kontemporer. Yogyakarta: Teras, 2011.

Ali, Muhammad Daud. Hukum Islam: Pengantar Ilmu Hukum dan Tata Hukum Islam di Indonesia. Jakarta: Rajagrafindo, 2001. Al-Mahalli, Imam Jalaluddin, dan Jalaluddin Imam As-Suyuthi. Terjemahan Tafsir Jalalain Berikut Asbabun Nuzul. Vol. 2. Bandung: Sinar Baru Algensindo, 2009.

${ }^{50}$ Fokusmedia, Kompilasi Hukum Islam, 9-10. 
158| Sudirman

An-Nawawi, Imam. Syarah Shahih Muslim. Jakarta: Pustaka Azzam, 2011.

"ArsipSurat Perjanjian Khithbah di Gaya Baru5, BandarSurabaya," n.d.

Azzam, Abdul Aziz Muhammad, dan Abdul Wahab Sayyed Hawwas. Fiqh Munakahat (Khitbah, Nikah dan Talak). Diterjemahkan oleh Abdul Majid Khon. Jakarta: Amzah, 2009.

Fokusmedia, Tim Redaksi. Kompilasi Hukum Islam. Bandung: Fokusmedia, 2007.

Kamal, Mukhtar. Asas-Asas Hukum Islam Tentang Perkawinan. Jakarta: Bulan Bintang, 1993.

Khallaf, Abdul Wahhab. Ilmu Ushul Fikih Kaidah Hukum Islam. Diterjemahkan oleh Faiz el Muttaqien. Jakarta: Pustaka Amani, 2003.

Mahfudh, Sahal. Solusi Problematika Aktual Hukum Islam Keputusan Muktamar, Munas, dan Konbes Nahdlatul Ulama (1926-2004 M). Surabaya: Khalista, 2007.

Mintosih, Sri. Pandangan Generasi Muda terhadap Perkawinan Adat di Kota Surabaya. Surabaya: Depdikbud, 1998.

Pasaribu, Chairuman, dan Suhrawardi K. Lubis. Hukum Perjanjian dalam Islam. 3 ed. Jakarta: Sinar Grafika, 1996.

Shomad, Abd. Hukum Islam Penormaan Prinsip Syariah Dalam Hukum Indonesia,. Jakarta: Kencana, 2012.

Syafi'i, Rahmad. Fiqih Muamalah. Bandung: Pustaka Setia, 2000.

Tihami, M. Ahmad, dan Sohari Sahrani. Fikih Munakahat: Kajian Fikih Nikah Lengkap. Jakarta: Rajawali, 2009.

Zuhaili, Wahbah. Al-Fiqh al-Islâmī wa Adillatuhu. Beirut: Dar alFikr, 1997.

- - - Fiqih Imam Syafi'i: Mengupas Masalah Fiqhiyah Berdasarkan Al-Qur' an dan Hadits, terj. Diterjemahkan oleh Muhammad Afifi dan Abdul Hafiz. Jakarta: Almahira, 2010. 
Analisis Hukum Islam terhadap Sanksi Pembatalan Khitbah Nikah I159

\section{Daftar Informan}

Kasmo. Sesepuh Bandar Surabaya dan Seputih Surabaya, 13 Februari 2016.

Marfi. Tokoh Pemuda Kampung Gaya Baru 5, 22 Januari 2016.

Mino. Kadus Jogja 5, Kampung Gaya Baru 5, Bandar Surabaya, 21 Januari 2016.

Muhaimin, Ahmad. Tokoh Agama Seputih Surabaya dan Bandar Surabaya, 22 Januari 2016.

Muhtar, Ali. Ketua KUA Bandar Surabaya, 3 Februari 2016.

Murihono. Anggota keluarga SR bin TR, 22 Januari 2016.

NM. Keluarga Saudara J bin G, 13 Februari 2016.

Nurdin. Tokoh Masyarakat Gaya Baru III, Seputih Surabaya, 10 Januari 2016.

Panut, Ahmad. Tokoh Agama Bandar Surabaya, 22 Januari 2016. 
160| Sudirman 